\title{
Multi-criteria Evaluation of Railway Transport Using Evaluation Method
}

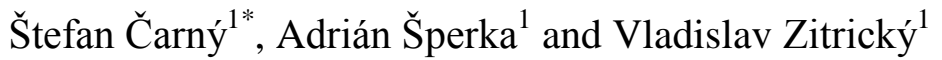

${ }^{1}$ University of Žilina., Department of railway transport, Univerzitná 8215/1, Žilina, SlovakRepublic; Email: carny.stefan@fpedas.uniza.sk, adrian.sperka@fpedas.uniza.sk, vladislav.zitricky@fpedas.uniza.sk

\section{*Corresponding Author: Štefan Čarný}

Received: 16 October 2020; Revised: 28 October 2020; Accepted: 4 November 2020; Published: 30 November 2020

\begin{abstract}
The arrival of new customers along the new Iron Silk Road also brings new transport opportunities. The liberalization of railway transport has created many wagons over the railway market throughout the EU, especially in the field of freight transport. Choosing the preferable carrier that can fit the needs of customers is challenging. Each rail freight operator currently shapes its profile by focusing on a specific group of commodities as a matter of priority. By specializing, they gain a dominant market position in their sector that helps them to maintain and expand their clientele. The article aims at bringing a decisive system with clear rules and standards for choosing the right business partner in the freight railway market. The article is designed as a case study that starts with an analysis of four different freight carriers. Other parts of the article are about the evaluation of their ability to meet the needs of a customer.
\end{abstract}

Keywords: Railway transport, multi-criteria analysis, evaluation method, railway freight carrier

\section{Introduction}

The use of multi-criteria decision-making has the task of bringing the subjectivity of decisionmaking closer to the level of an empirically evaluable process, by means of which we can simplify the choice of a carrier or broaden our horizons. Before performing a multi-criteria analysis, it is necessary to collect extensive data using various information channels, and then formulate them as a problem of selecting a suitable variant [1].

With the help of mathematical processes, we then select a suitable carrier, who we should contact. From this perspective, a multi-criteria analysis serves as a tool for the top management in strategic decision-making [2]. In terms of its use for international transport, it is possible to apply it to customers who are not familiar with our market or use it in other forms, where the research could be done by the necessary selection of variants, e.g. transport route, etc [3-5]. 
In this work, we will formulate a case study of a fictitious customer who chooses a suitable carrier. We focused on qualitative and quantitative indicators, which we objectively evaluated using empirical relationships and dependencies and the knowledge of arithmetic.

\section{The Scoring Method}

The scoring method is based on the evaluation of the supplier, who is awarded points for all the criteria defined by the company. The final rating is determined using a weighted arithmetic mean. This final score is compared with the maximum number of achievable points. The result is a classification of suppliers, which forms the basis for the final selection of a suitable carrier. Each company specifies its own evaluation criteria, considering the selection needs. In practice, the socalled basic criteria ("areas" for the purposes of this study), such as price, quality, technical aspects, logistics, environmental protection, and the like.

The scoring method in this case study is based on the principle described above, defining certain evaluation criteria, and then assigning these criteria to individual carriers according to their ability to meet or failing to meet this criterion [6-8]. The rating is defined on a scale from 0 to 100 .

\section{Two-Stage Evaluation}

In addition, each criterion is assigned a percentage weight depending on the significance of the criterion for the company in the transport of the commodity - so the so-called a two-stage evaluation, ensuring a greater degree of reflection of the importance of the criterion according to its weight for the company. It is important that the criterion in the sum of the column reaches $100 \%$ - at the end of the selection of the carrier in the evaluated area, the sums of the products of the assigned weight and the given criterion in $\%$ and assigned points in values according to how they were defined are then taken into account. The carrier with the highest total number of points for all criteria is the most suitable for the evaluated area [9-13].

\section{Summary Evaluation of Carriers}

The result of the evaluation is the choice of the carrier. This is also a two-stage evaluation considering the evaluated area as a whole, regardless of the partial evaluated criteria in it. The evaluation of the sub-criteria falls mainly to the specialized departments within the designated company, the overall allocation of weights to the evaluated areas as a whole and to the closer management of the company on which the final decision on carrier selection rests, especially in regard to needs, strategies and economy of the undertaking [6]. 


\section{Characteristics of Selected Carriers}

Before we can evaluate the selected carriers, it is necessary to collect information about their portfolio of offered services, technical base, financial health and the like. For this practical part, we chose carriers operating in the Slovak Republic [6].

In the following figure (Fig. 1) shows the logo of each carrier and their marketing image.

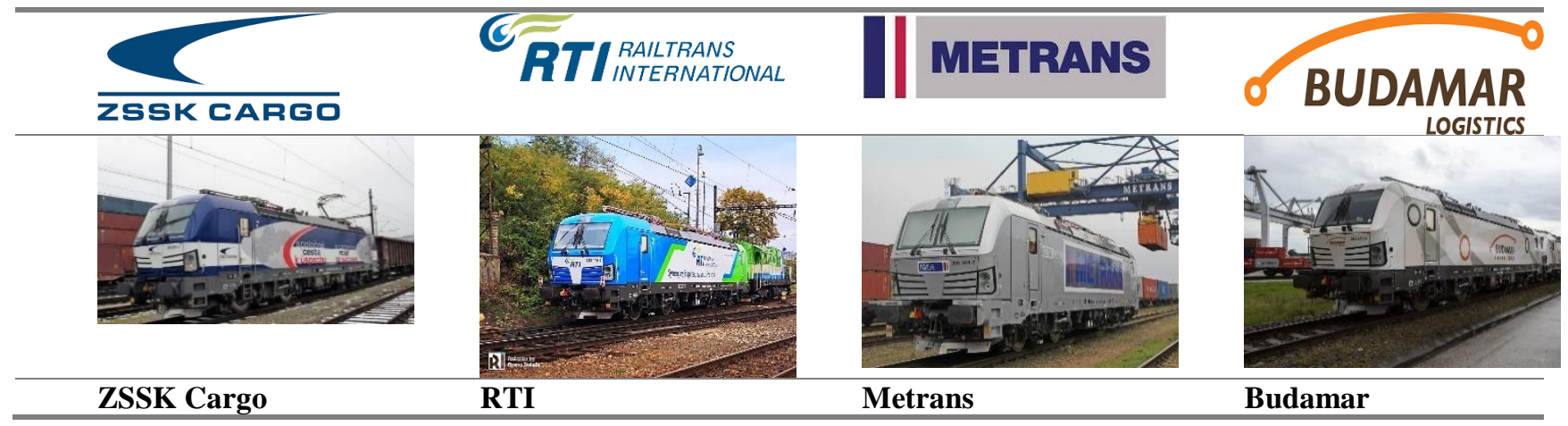

Fig. 1 Graphic representation of the compared carriers, their logo and image. Source: authors

\subsection{Railway Company Cargo Slovakia plc.}

Railway company ZSSK Cargo a. s. is national freight carrier in Slovak republic. As a national freight carrier offers most of the services and it is also capable of transportation of various types of cargo. ZSSK Cargo a. s. provides as an only carrier in Slovak Republic the transport of single carrier consignment (Table 1).

Table 1 Brief overview of information about the carrier ZSSK Cargo. Source: [14]

\begin{tabular}{llc}
\hline & Yes & No \\
\hline Tariff & $\mathrm{X}$ & $\mathrm{X}$ \\
\hline Transport conditions & Catalogue of carriages of all categories \\
\hline Rolling stock & $\mathrm{X}$ \\
\hline Interoperability & $\begin{array}{l}\text { Catalogue of carriages of all categories. The national carrier } \\
\text { that provide transport of all commodities, including the } \\
\text { individual carriage consignment. }\end{array}$ \\
\hline
\end{tabular}

\subsection{Railtrans International}

Railtrans international, as a company provides organisation of logistics services and transportation of its selected group of goods (Table 2). The carrier is offering mostly transportation of liquid material such as chemicals, JET fuel, benzene destiles or diesel. In this study, we have included its subsidiary RTI carriers into the characteristics as an owner of class E carriers which are used for transportation of coal or fertilizers etc. $[15,16]$. 
Table 2 Brief overview of information about the carrier RTI. Source: [16]

\begin{tabular}{lll}
\hline & Yes & No \\
\hline Tariff & & $\mathrm{X}$ \\
\hline Transport conditions & & $\mathrm{X}$ \\
\hline Rolling stock & Only carriages of classes Z and E & \\
\hline Interoperability & $\mathrm{X}$ & $\begin{array}{l}\text { Transportation of petroleum distillates, aromatics, } \\
\text { benzene products, JET products and rig oil products }\end{array}$ \\
\hline Specification &
\end{tabular}

\subsection{Metrans Danubia}

Metrans Danubia is a provider of all-inclusive just-in-time intermodal rail-road transport, operating its own trains with sea freight from / to the Czech Republic, Slovakia, Hungary and new services to the hinterland of Germany and Austria, which are connected by rail with major European ports, including Hamburg, Bremerhaven, Rotterdam and Duisburg, or the main southern railway connections to Koper, Trieste, Rijeka (Table3). METRANS has built its own network of highly sophisticated container terminals and modern railway interception terminals in the Czech Republic, Slovakia and Austria [15].

Table 3 Brief overview of information about the carrier Metrans Danubia. Source: [15]

\begin{tabular}{lll}
\hline & Yes & No \\
\hline Tariff & & X \\
\hline Transport conditions & X \\
\hline Rolling stock & $\begin{array}{l}\text { Only platform } \\
\text { carriages }\end{array}$ & \\
\hline Interoperability & X & The largest intermodal transport operator in the Slovak Republic \\
\hline Specification &
\end{tabular}

\subsection{Budamar Logistics}

Budamar logistics offers international forwarding and logistics, while in the market of Central and Eastern Europe it has a leading position (Table 4). The BUDAMAR GROUP portfolio includes important companies such as the international forwarder BUDAMAR LOGISTICS, as well as the railway carriers LOKORAIL, CENTRAL RAILWAYS and INTER CARGO, the company Slovenská plavba a př́stavy, the operator of the Bulk Transshipment Slovakia transhipment terminal [14].

Table 4 Brief overview of information about the carrier Budamar logistics. Source: authors

\begin{tabular}{lll}
\hline & Yes & No \\
\hline Tariff & $\mathrm{X}$ & \\
\hline Transport conditions & $\mathrm{X}$ & \\
\hline Rolling stock & Catalogue of wagons of all categories & \\
\hline Interoperability & $\mathrm{X}$ & \\
\hline
\end{tabular}




\section{A Practical Example of Carrier Evaluation in the Form of Multi-Criteria Decision-Making}

For each commodity, all four selected carriers were evaluated and the resulting evaluation, whether high or low, depends on the extent to which each carrier is able to deal with the transport of that commodity. The transport that the carrier specializes in plays a big role. For example, ZSSK Cargo, as the largest national state-owned freight carrier, specializes in the transportation of all possible types of commodities and logically has an advantage over other carriers in the transportation of various commodities. These and other specific evaluation issues are further elaborated in the relevant tables with the evaluated areas $[17,18]$.

Evaluation tables were created in total for three different evaluation areas. Each area has undefined evaluation criteria, which contain a brief description of the options in the criterion with assigned points [19]. Points were then allocated to all carriers in the commodity - to improve the transparency, we replaced the names of carriers in the tables following: A - ZSSK Cargo, B RTI, C - Metrans Danubia, D - Budamar. The resulting average ratings in the area are shown in Table 9 which is followed by the procedure described in the theoretical part.

\subsection{Evaluation of Multi-criteria Decision-making Carrier Selection}

In Figure 2, we evaluated 3 basic criteria - railway carriages, international operation, interoperability, efficiency, and capacity. Railway carriages have the greatest weight in various commodities, where the diversity of the series of carriages available to the carrier is decisive. For the automotive and container commodities, this criterion is not that important, as a limited number of rows of carriages are sufficient for the transport. In international transport and interoperability, the situation is completely opposite, as the transport of cars and containers is usually carried out abroad in one of the ports in the north or south of Europe, and thus have a relatively high weight. In the category of miscellaneous commodities, domestic transport is assumed, and therefore the lowest weight is assigned. Efficiency and capacity are important for all commodities, and therefore similar weights in the range of $20-40 \%$ are assigned in this case [20].

\begin{tabular}{|c|c|c|c|c|c|c|c|c|c|c|c|c|c|c|c|c|c|c|c|c|c|c|}
\hline \multirow{2}{*}{\multicolumn{3}{|c|}{ Evaluation of the area - technical side of the rolling stock }} & \multicolumn{20}{|c|}{ Weight for criterium in \% and allocation points } \\
\hline & & & \multicolumn{5}{|c|}{ Automotive } & \multicolumn{5}{|c|}{ IPJ } & \multicolumn{5}{|c|}{ Liquids } & \multicolumn{5}{|c|}{ Various commodity } \\
\hline Evaluation criterium & Brief description & Points & $\%$ & A & B & $\mathrm{C}$ & D & $\%$ & A & B & C & D & $\%$ & A & B & $\mathrm{C}$ & D & $\%$ & A & $\mathrm{B}$ & $\mathrm{C}$ & D \\
\hline \multirow{3}{*}{ Railway wagons } & $\begin{array}{l}\text { The carrier has at its disposal a series of wagons for the } \\
\text { transport of all commodities }\end{array}$ & 100 & \multirow{3}{*}{$20 \%$} & \multirow{3}{*}{$100 \mid$} & \multirow{3}{*}{0} & \multirow{3}{*}{0} & \multirow{3}{*}{70} & \multirow{3}{*}{$20 \%$} & \multirow{3}{*}{70} & \multirow{3}{*}{0} & \multirow{3}{*}{100} & \multirow{3}{*}{70} & \multirow{3}{*}{$20 \%$} & \multirow{3}{*}{70} & \multirow{3}{*}{100} & \multirow{3}{*}{0} & \multirow{3}{*}{70} & \multirow{3}{*}{$20 \%$} & \multirow{3}{*}{$\mid 100$} & \multirow{3}{*}{70} & \multirow{3}{*}{0} & \multirow{3}{*}{70} \\
\hline & $\begin{array}{l}\text { The carrier has at its disposal a number of wagons for the } \\
\text { transport of most commodities }\end{array}$ & 70 & & & & & & & & & & & & & & & & & & & & \\
\hline & The carrier does not have the number of wagons available to & 0 & & & & & & & & & & & & & & & & & & & & \\
\hline \multirow{3}{*}{$\begin{array}{l}\text { International transport } \\
\text { operations and } \\
\text { interoperability }\end{array}$} & $\begin{array}{l}\text { The carrier has at its disposal vehicles capable of } \\
\text { international / transit transport in the surrounding states }\end{array}$ & 100 & \multirow{3}{*}{$40 \%$} & \multirow{3}{*}{100} & \multirow{3}{*}{60} & & & & & & & & & & & & & & & & & \\
\hline & $\begin{array}{l}\text { The carrier has at its disposal vehicles capable of } \\
\text { international / transit transport only in selected neighboring }\end{array}$ & 60 & & & & 100 & 60 & $40 \%$ & 100 & 20 & 100 & 60 & $40 \%$ & 100 & 100 & 20 & 100 & $40 \%$ & |60 60 & 20 & 20 & 60 \\
\hline & $\begin{array}{l}\text { The carrier does not have at its disposal vehicles capable of } \\
\text { international transport, possibly has only selected neighboring }\end{array}$ & 20 & & & & & & & & & & & & & & & & & & & & \\
\hline & $\begin{array}{l}\text { The carrier is able to deliver the required number of wagons } \\
\text { for loading within the specified period }\end{array}$ & 100 & & & & & & & & & & & & & & & & & & & & \\
\hline Effectivity and capacity & $\begin{array}{l}\text { The carrier needs more time to deliver the required number } \\
\text { of wagons for loading }\end{array}$ & 50 & $40 \%$ & 100 & 0 & 0 & 100 & $40 \%$ & 50 & 0 & 100 & 100 & $40 \%$ & 50 & 100 & 0 & 50 & $40 \%$ & $\mid 100$ & 0 & 0 & 60 \\
\hline & $\begin{array}{l}\text { The carrier is not able to deliver the required number of } \\
\text { wagons for loading }\end{array}$ & 0 & & & & & & & & & & & & & & & & & & & & \\
\hline & Overall avera & e rating & $100 \%$ & 100 & 24 & 40 & 78 & $100 \%$ & 74 & 8 & 100 & 78 & $100 \%$ & 74 & 100 & 8 & 74 & $100 \%$ & 84 & 22 & 8 & 62 \\
\hline
\end{tabular}

Fig. 2 Evaluation of the area - technical status of rolling stock. Source: authors 
The area of price conditions shown in Figure 3 is one of the most important in terms of evaluation, as the price will always be a critical factor in deciding on almost anything. The first criterion is the tariff and transport conditions, which have been assigned the greatest weight for different commodities, as for these types of transport it is necessary to have an overview of the conditions under which the carrier performs these transports and also whether it is not used for specific types of commodities - another way in calculating the freight. Another criterion - a room for negotiating the contract price - was given the highest weight for the IPJ commodity, because there is a lot of downward pressure on prices for this commodity, especially due to the operation of a number of intermodal transport operators. If the carrier is able to satisfy customers as much as possible, he can generate demand for the transport of this commodity in this regard. The other two criteria, which are readiness to reduce import and price stability, were assigned a weight of about 15-30\%. These criteria apply without distinction to all commodities and are considered equally important according to the weight assigned.

\begin{tabular}{|c|c|c|c|c|c|c|c|c|c|c|c|c|c|c|c|c|c|c|c|c|c|c|}
\hline \multirow{2}{*}{\multicolumn{3}{|c|}{ Evaluation of the area - pricing conditions }} & \multicolumn{20}{|c|}{ Weight for criterium in \% and allocation points } \\
\hline & & & \multicolumn{5}{|c|}{ Automotive } & \multicolumn{5}{|c|}{ IPJ } & \multicolumn{5}{|c|}{ Liquids } & \multicolumn{5}{|c|}{ Various commodity } \\
\hline Evaluation criterium & Brief description & Points & $\%$ & $\mathrm{~A}$ & $\mathrm{~B}$ & $\mathrm{C}$ & D & $\%$ & A & $\mathrm{B}$ & $\mathrm{C}$ & D & $\%$ & A & B & $\mathrm{c}$ & D & $\%$ & $\mathrm{~A}$ & $\mathrm{~B}$ & C & $\mathrm{D}$ \\
\hline \multirow{2}{*}{ Tariff and transport } & $\begin{array}{l}\text { The tariff and all transport conditions are published on the } \\
\text { carriers website }\end{array}$ & 100 & \multirow[b]{2}{*}{$10 \%$} & \multirow{2}{*}{100} & \multirow{2}{*}{40} & \multirow{2}{*}{0} & \multirow{2}{*}{0} & \multirow[b]{2}{*}{$10 \%$} & \multirow[b]{2}{*}{100} & \multirow[b]{2}{*}{40} & \multirow{2}{*}{0} & \multirow[b]{2}{*}{0} & \multirow[b]{2}{*}{$10 \%$} & \multirow[b]{2}{*}{100} & \multirow[b]{2}{*}{40} & \multirow[b]{2}{*}{0} & \multirow[b]{2}{*}{40} & \multirow[b]{2}{*}{$10 \%$} & \multirow[b]{2}{*}{100} & \multirow[b]{2}{*}{40} & \multirow[b]{2}{*}{0} & \multirow[b]{2}{*}{40} \\
\hline & \begin{tabular}{|l|} 
The carrier does not have published tariff, only the transport \\
The carrier does not have published tariff or the transport \\
\end{tabular} & $\frac{40}{0}$ & & & & & & & & & & & & & & & & & & & & \\
\hline \multirow{3}{*}{$\begin{array}{l}\text { Negotiation space and } \\
\text { contractual conditions }\end{array}$} & $\begin{array}{l}\text { The carrier is trying to meet the needs of the competition, } \\
\text { flexible approach }\end{array}$ & 100 & \multirow{3}{*}{$40 \%$} & \multirow{3}{*}{60} & \multirow{3}{*}{60} & & & & & & & & & & & & & & & & & \\
\hline & $\begin{array}{l}\text { The carrier enters into price negotiations partly, under the } \\
\text { certain conditions or compromises }\end{array}$ & 60 & & & & 0 & 20 & $40 \%$ & 60 & 0 & 100 & 20 & $40 \%$ & 60 & 100 & 0 & 20 & $40 \%$ & 60 & 60 & 0 & 20 \\
\hline & The carrier seldom negotiates the final prices, not flexible & 0 & & & & & & & & & & & & & & & & & & & & \\
\hline Willingness to proceed with & $\begin{array}{l}\text { The carrier allways tries to provide a percentage reduction in } \\
\text { consigment, depending on the type and quantity of goods }\end{array}$ & 100 & & & & & & & & & & & & & & & & & & & & \\
\hline $\begin{array}{l}\text { reduction in the rate of } \\
\text { import }\end{array}$ & $\begin{array}{l}\text { The carrier provides a percentage reduction in consigment } \\
\text { only in the case of regular shippments }\end{array}$ & 50 & $30 \%$ & 100 & 50 & 0 & 20 & $30 \%$ & 50 & 100 & 100 & 20 & $30 \%$ & 100 & 50 & 0 & 50 & $30 \%$ & 100 & 50 & 0 & 50 \\
\hline & The carrier hardly provides a percentage reduction in & 0 & & & & & & & & & & & & & & & & & & & & \\
\hline & \begin{tabular}{|l} 
Prices increase after several years \\
\end{tabular} & 100 & & & & & & & & & & & & & & & & & & & & \\
\hline Price stability & \begin{tabular}{|l|} 
Prices increase after every year \\
Prices ncrease several times a year \\
\end{tabular} & $\begin{array}{c}70 \\
0\end{array}$ & $20 \%$ & 70 & 70 & 0 & 0 & $20 \%$ & 70 & 70 & 100 & 0 & $20 \%$ & 70 & 100 & 0 & 70 & $20 \%$ & 70 & 100 & 0 & 0 \\
\hline & Overall averag & e rating & $100 \%$ & 78 & 57 & 0 & 14 & $100 \%$ & 63 & 48 & 90 & 14 & $100 \%$ & 78 & 79 & 0 & 41 & $100 \%$ & 78 & 63 & 0 & 27 \\
\hline
\end{tabular}

Fig. 3 Evaluation of the area - price conditions. Source: authors

The last area in Figure 4, which assesses the availability and additional services during transport, we defined four criteria - the place of loading and unloading, the level of service of intermodal terminals, additional charges and services and the ability to transport extraordinary and dangerous consignments.

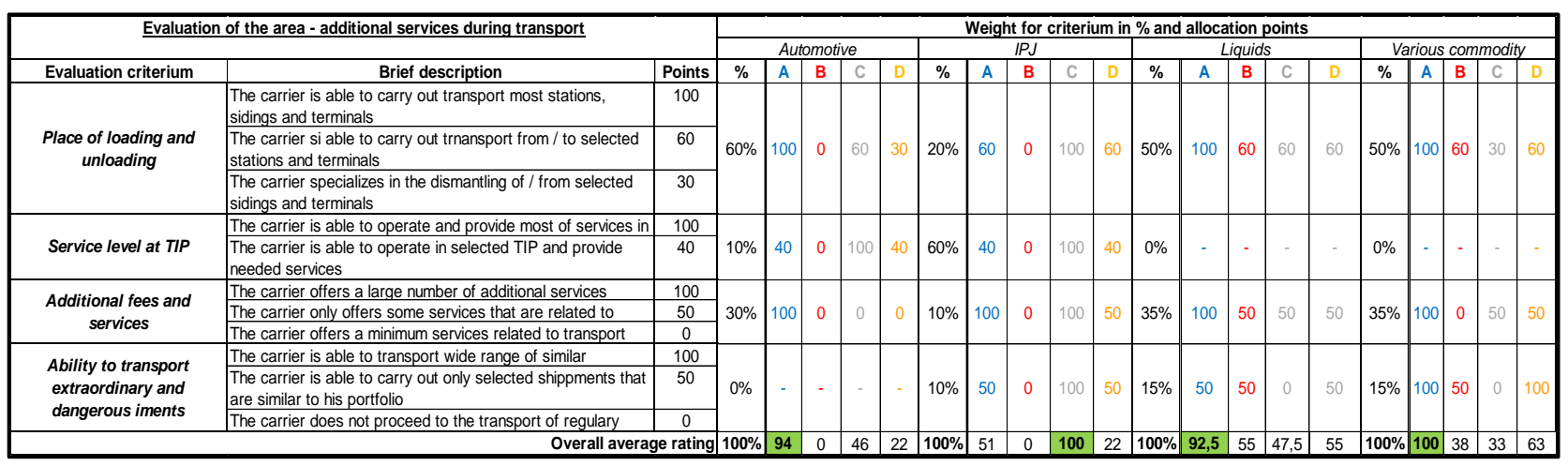

Fig. 4 Evaluation of the area - availability of additional services during transport. Source: authors 
The criterion of the loading and unloading place is the lowest weight assigned to the IPJ commodity, as these shipments are mostly specific. The imaginary commodity of liquid can be used as a way of supplying companies with fuel. There are transports that are also located to service stations that are located outside the main lines. For this reason, we have assigned a higher $\%$ by a weight to the commodity. The automotive commodity has the highest weight, as it is important for the carrier to be able to serve quality stations and sidings into them, where there is a specific car manufacturer with a demand for the car transport - for example, where it is not possible to handle electric traction. In the category of various commodities, the weight assignment is quite logical, as the place of loading / unloading can be anywhere in the country.

The level of TIP service is essentially only important for the IPJ commodity, where a weight of $60 \%$ has been assigned, as these are usually transported between the terminals themselves, rarely loaded / unloaded by rail takes place elsewhere. A very small value of $10 \%$ was also assigned to the automotive commodity - it may be the case that the company wants to transport cars in containers, but this method is not common for this commodity. In the case of different commodities, this criterion does not play a role, and therefore no points were allocated here in the same way for a liquid commodity. Under the criterion of additional charges and services, the highest weight was assigned to various commodities and automotive, where the customer may require some additional services, such as the completion of the consignment note by the carrier, etc. in the case of the IPJ, this has not been given much importance, especially in regard to the weight of other criteria that are more important for this commodity. The ability to transport dangerous goods plays an important role in the transport of liquids if we are considering the transport of petroleum products or gases $[3,5]$.

\section{Evaluation of Multi-criteria Analysis of Selecting the Carrier}

The score should result in the final selection of the carrier for the commodity. In contrast to the weight assigned by individual departments for defined criteria within the evaluated areas, another final weight assignment is applied, but now from the resulting average evaluation for the whole area from Tables 2-4, depending on the importance of the designated area for the company. This assessment already reflects the final idea of the close management of the company on which the strategic decision lies and can thus easily favour a more important or less important criterion for them. Again, the carrier with the highest point total in the given commodity wins.

In table no. 9, the area of price conditions was the most preferred in terms of $50 \%$ weight, as it will always be largely critical with regard to the financial situation of the company and it is important that the chosen carrier cooperates in this regard. What follows is the area of the technical side of the vehicle fleet with $30 \%$ - it is necessary that the chosen carrier is reliable in terms of 
country availability and also in terms of capacity - that is, that the transport runs smoothly and without further problems. Availability and additional services in transport not exceeding 20\% -, this area is not so important for the company compared to the previous two, although we take into account that in Figure 5 some criteria do not have points assigned due to the impossibility of using them for the given commodities.

\begin{tabular}{|c|c|c|c|c|c|c|c|c|c|c|c|c|c|c|c|c|c|}
\hline \multirow{2}{*}{ Overall evaluation of carriers } & \multirow{2}{*}{ Weight } & \multicolumn{4}{|c|}{ A utomotive } & \multicolumn{4}{|c|}{$\mathbb{P J}$} & \multicolumn{4}{|c|}{ Liquids } & \multicolumn{4}{|c|}{ Various comm odity } \\
\hline & & A & $\mathrm{B}$ & $\mathrm{C}$ & $\mathrm{D}$ & $\mathrm{A}$ & $\mathrm{B}$ & $\mathrm{C}$ & $\bar{D}$ & A & $\mathrm{B}$ & $\mathrm{C}$ & $\mathrm{D}$ & $\mathrm{A}$ & $\mathrm{B}$ & $\mathrm{C}$ & D \\
\hline $\begin{array}{c}\text { Technical perspective of the } \\
\text { vehicle fleet }\end{array}$ & $30 \%$ & 30 & 7,2 & 12 & 23 & 22 & 2,4 & 30 & 23,4 & 22,2 & 30 & 2,4 & 22,2 & 25,2 & 6,6 & 2,4 & 18,6 \\
\hline Price conditions & $50 \%$ & 39 & 28,5 & 0 & 7 & 32 & 24 & 45 & 7 & 39 & 39,5 & 0 & 20,5 & 39 & 32 & 0 & 13.5 \\
\hline $\begin{array}{c}\text { Avallability of services and } \\
\text { additional charges }\end{array}$ & $20 \%$ & 18,8 & 0 & 9,2 & 4,4 & 10 & 0 & 20 & 4.4 & 18,5 & 11 & 9,5 & 11 & 20 & 7,5 & 6,5 & 12,5 \\
\hline Overall rating & $100 \%$ & 87,8 & 35,7 & 21 & 35 & 84 & 28 & 95 & 34,8 & 79,7 & 80,5 & 12 & 53,7 & 84,2 & 46 & 8,9 & 44,6 \\
\hline
\end{tabular}

Fig. 5 Overall evaluation of carriers for individual commodities. Source: authors

The result of the scoring method can be clearly compared in the form of graphical interpretation, using a web diagram. This is shown in the form of a triangle. Inside, a network is created that represents the scale for the points allocated to each commodity, from minimum to maximum. Subsequently, points are created there, which were created by assigning values to individual carriers. After their connection, a pattern is created, showing the performance of the carrier in individual areas. The larger the area of the figure is, the better the carrier in the evaluated area and vice versa will be.

\subsection{Evaluation of the Automotive Commodity}

The most advantageous carrier for the automotive commodity is ZSSK cargo, as it provides excellent services related to this commodity. We evaluated Metrans due to the frequent use of the automotive commodity in the form of transport with the help of IPJ (Fig. 6).

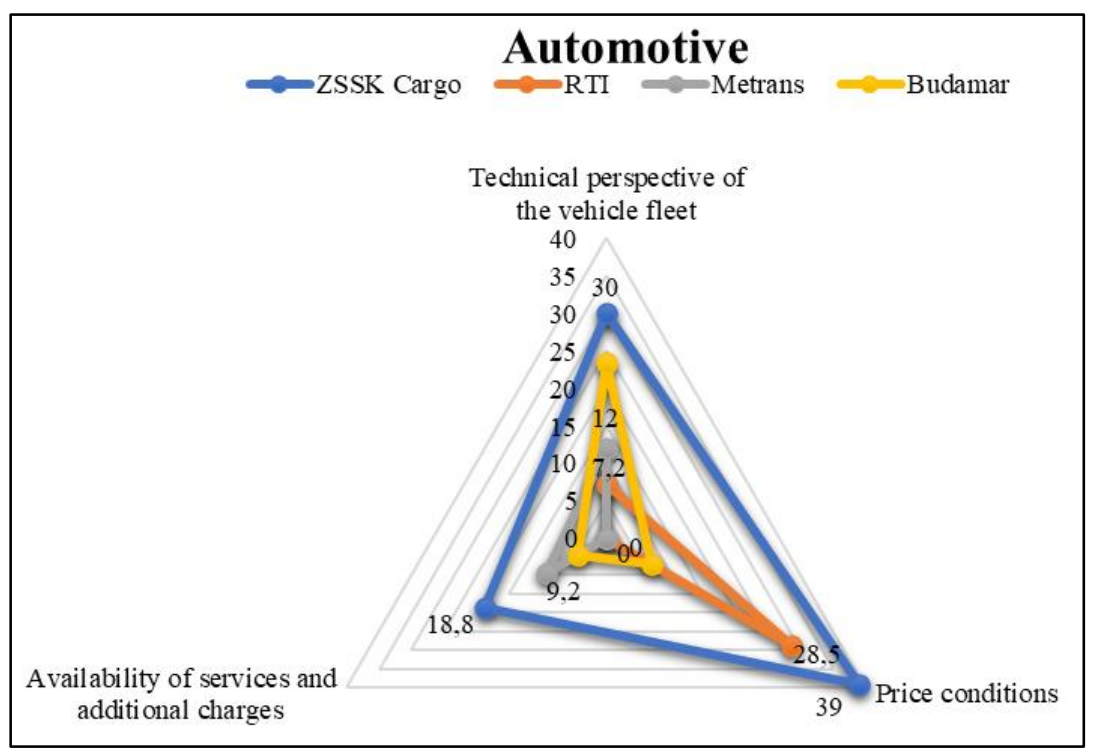

Fig. 6 Graphical representation of the evaluation on the automotive comodity. Source: authors 


\subsection{Evaluation of Various Commodities}

ZSSK Cargo, as the only carrier, provides services of local lines in the form of handling trains. For a new small entrepreneur who decides that he would like to carry out his activities and provide logistic processes in the form of rail transport, he would use the services of a national carrier. Budamar provides its services only on a narrower scale. No competing carrier operates a small local burden transfer service (Fig. 7).

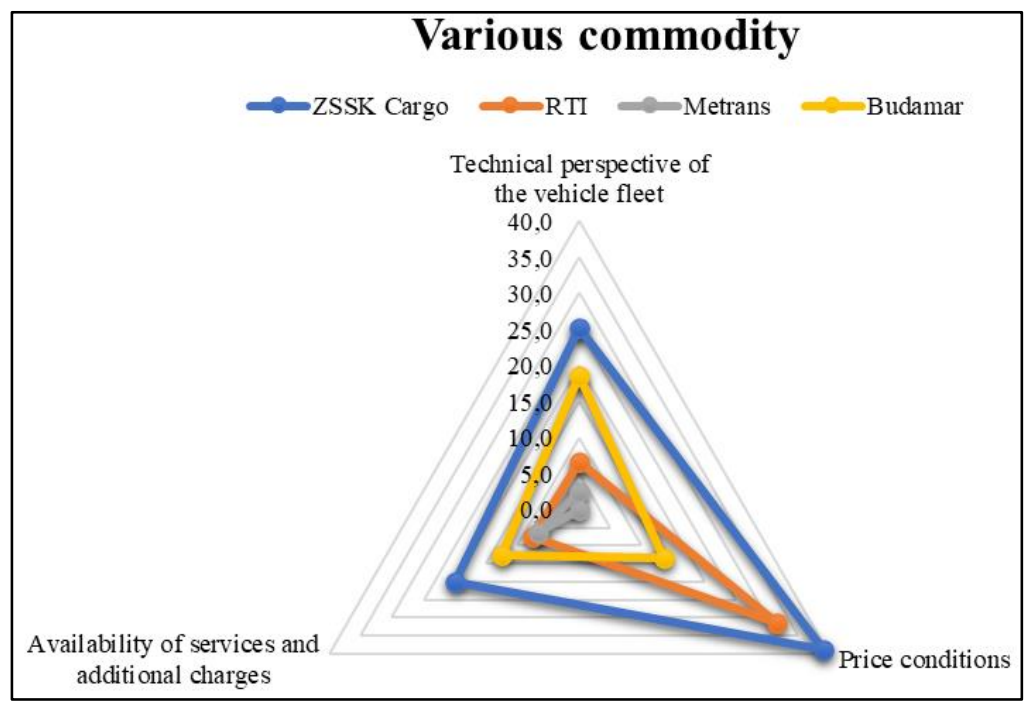

Fig. 7 Graphical representation of the evaluation on the various commodity. Source: authors

\subsection{Evaluation of the Intermodal Commodity}

In the current market, Metrans Danubia is the largest carrier in the IPJ commodity; as confirmed by the multi-criteria evaluation. Competitors of private carriers other than Budamar, who are also gaining grounds in this market, do not currently have an expansion of the same scope as Metrans (Fig. 8).

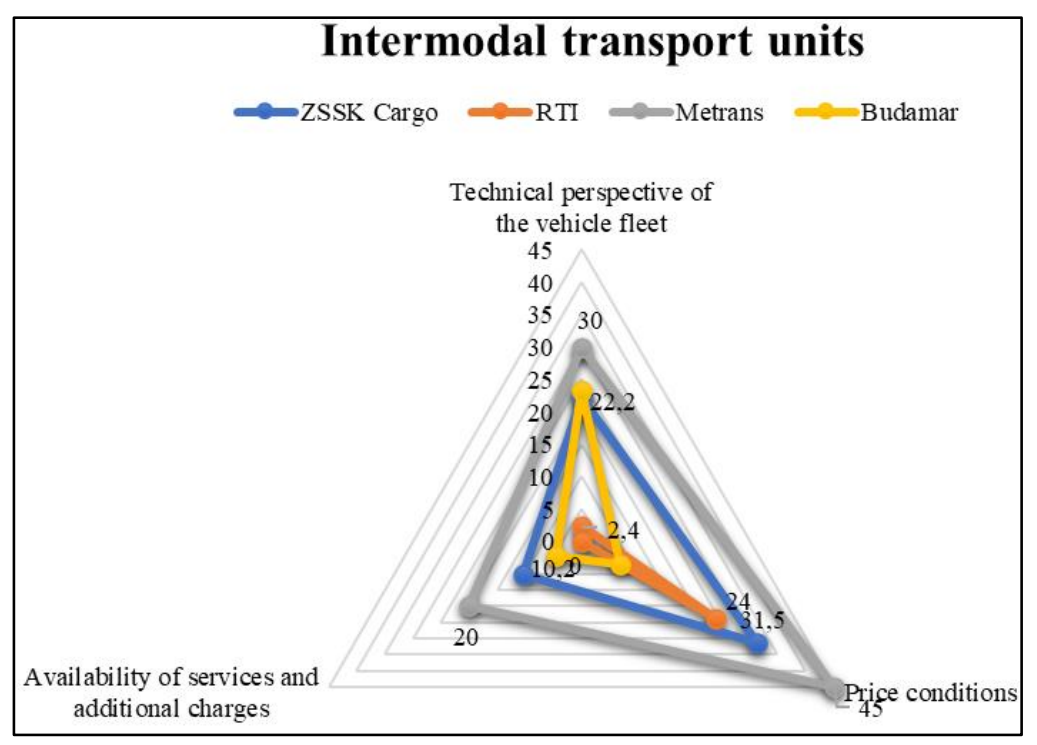

Fig. 8 Graphical representation of the evaluation on the intermodal containters. Source: authors 


\subsection{Evaluation of the Liquid Materials Commodity}

The transport of liquids, in which the company RTI specializes, is known on the market in the Slovak Republic mainly due to the modern vehicle fleet, representing the company's abroad image. This carrier specializes mainly in the transportation of petroleum products from the Slovnaft factory, which makes it a leader in liquid commodities (Fig. 9).

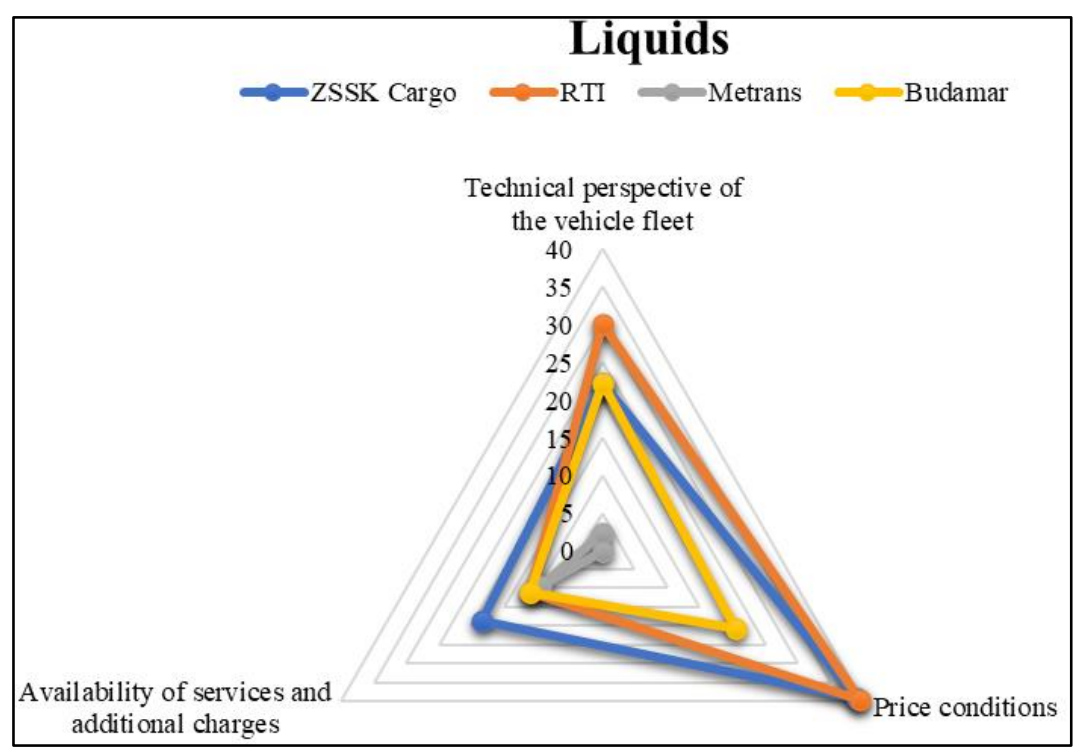

Fig. 9 Graphical representation of the commodity liquid materials. Source: authors

\section{Conclusion}

The issue of selecting the carrier represents a key role in the entry of a new or foreign customer into the railway market. To direct him, it is necessary to develop certain tools that would help him in choosing a carrier.

Multi-criteria decision-making should help the senior management to decide between several options. By evaluating the information gathered, we obtained a sufficient overview so that we could determine and prepare a decision table.

The decision tables can be applied in the selection of a suitable transport coordinator or forwarding company, or we can also use this analysis in the selection of a suitable train path, for example when tracking transcontinental rail transport.

\section{Acknowledgements}

The paper is supported by the VEGA Agency by the Project 1/0791/18"The Assessment of Economic and Technological Aspects in the Provision of Competitive Public Transport Services in Integrated Transport Systems" that is solved at Faculty of Operation and Economics of Transport and Communications, University of Žilina. 


\section{References}

[1] Dolinayova, A., Cerna, L. \& Zitricky, V. (2018). The role of railway transport in East-West traffic flow conditions of the Slovak Republic. Studies in Systems, Decision and Control 155, 121-169. DOI: 10.1007/978-3-319-78295-9_3.

[2] Dedík, M., Gašparík, J., Záhumenská, Z., Lupták, V. \& Hřebíček, Z. (2018). Proposal of the measures to increase the competitiveness of rail freight transport in the EU. Nase More 65(4 Special issue), 202-207. DOI:10.17818/NM/2018/4SI.7.

[3] Bukova, B., Brumercikova, E. \& Kondek, P. (2016). The multi-criteria decision in the allocation of logistic centers in the EU. In Transport Means - Proceedings of the International Conference, 5-7 October, 2016 (pp. 784-788), Juodkrante, Lithuania: Kaunas University Technology Press, K. Donelaicio 73, Kaunas, LT 3006, Lithuania.

[4] Mikušová, N., Stopka, O. \& Stopkova, M. (2019). Application of multi-criteria decisionmaking methods for the area of recycling. TEM Journal - Technology Education Management Informatics 8(3), 827-835. DOI: 10.18421/TEM83-19.

[5] Bartuška, L., Stopka, O., Chovancová, M. \& Ližbetin, J. (2016). Proposal of optimizing the transportation flows of consignments in the distribution center. In Transport Means Proceedings of the International Conference, 5-7 October, 2016 (pp. 107-111), Juodkrante, Lithuania: Kaunas University Technology Press, K. Donelaicio 73, Kaunas, LT 3006, Lithuania.

[6] Abramović, B., Šipuš, D. \& Ribarić, M. (2018). Analysis of the organisation of railway freight undertaking: A case study of HZ Cargo ltd. MATEC Web of Conferences 235, art. no. 00001. DOI:10.1051/matecconf/201823500001.

[7] Madudova, E. \& Dávid, A. (2019). Identifying the derived utility function of transport services: Case study of rail and sea container transport. Transportation Research Procedia 40, 1096-1102. DOI:10.1016/j.trpro.2019.07.153.

[8] Mašek, J. \& Holenková, A. (2019). The comparative analysis of study programmes in the field of transport economics and operation. In Transport Means - Proceedings of the International Conference, 2-4 October, 2019 (pp. 48-53), Palanga, Lithuania: Kaunas University Technology Press, K. Donelaicio 73, Kaunas, LT 3006, Lithuania.

[9] Dolinayova, A., Loch, M. \& Camaj, J. (2016). Liberalization of the railway freight market in the context of a sustainable transport system. Transportation Research Procedia 14, 916-925. DOI:10.1016/j.trpro.2016.05.071. 
[10] Kubáňová, J., Kubasáková, I., Jagelčák, J. \& Jurga, L. (2019). The possibility of using an intermodal transport. In Transport Means - Proceedings of the International Conference, 2-4 October, 2019 (pp. 872-878), Palanga, Lithuania: Kaunas University Technology Press, K. Donelaicio 73, Kaunas, LT 3006, Lithuania.

[11] Lupták, V., Gašparík, J. \& Chovancová, M. (2017). Proposal for evaluating a connection quality within transport networks. MATEC Web of Conferences 134, art. no. 00033. DOI: 10.1051/matecconf/201713400033.

[12] Kampf, R., Stopka, O., Kubasakova, I. \& Zitricky, V. (2016). Macroeconomic evaluation of projects regarding the traffic constructions and equipment. Procedia Engineering 161, 15381544. DOI:10.1016/j.proeng.2016.08.623.

[13] Dolinayová, A., Loch, M., \& Kanis, J. (2015). Modelling the influence of wagon technical parameters on variable costs in rail freight transport. Research in Transportation Economics 54, 33-40. DOI:10.1016/j.retrec.2015.10.023.

[14] ZSSK Cargo a. s. (2019). Yearly report of ZSSK Cargo a. s, 2019. https://www.zscargo.sk.

[15] Danubia Metrans. (2019). Yearly report of Danubia Metrans 2019. https://www.metrans.eu.

[16] Rail trans international. (2019). Yearly report of Rail trans international 2019. https://www.railtrans.eu.

[17] Št’astniak, P., Smetanka, L. \& Drozdziel, P. (2019). Computer aided simulation analysis for wear investigation of railway wheel running surface. Diagnostyka 20(3), 63-68. DOI: $10.29354 / \mathrm{diag} / 111569$.

[18] Fedorko, G. \& Weiszer, M. (2012). Configuring the parameters of multi-objective evolutionary algorithm for integrated timetabling and vehicle scheduling in public transport. In CLC 2012: Carpathian Logistics Congress, 7-9 November 2012 (pp. 435-440). Jesenik, Czech Republic.

[19] Szumska, E., Pawełczyk, M. \& Pistek, V. (2019). Evaluation of the Life Cycle Costs for urban buses equipped with conventional and hybrid drive trains. The Archives of Automotive Engineering - Archiwum Motoryzacji 83(1), 73-86. DOI: 10.14669/AM.VOL83.ART5.

[20] Skrucany, T., Kendra M., Kalina, T., Jurkovic, M., Vojtek, M. \& Synak, F. Environmental Comparision of Different Transport Modes. Nase More 65(4), 192-196. DOI: 10.17818/NM/2018/4SI.5. 